\title{
INTERMIDIALIDADE E UMA APROXIMAÇÃO INTERDISCIPLINAR ENTRE LITERATURA E VIDEOARTE
}

\begin{abstract}
Fernanda Paixão Araújo Pinto ${ }^{1}$
Resumo: O artigo analisa a interface interdisciplinar entre a poética de Edgar Allan Poe em "Aventuras de Arthur Gordon Pym" e o vídeo The Passing, de Bill Viola. Discutem-se conceitos da teoria comunicacional e dos estudos comparados, a fim de relacionar uma possibilidade interpretativa e comparativa entre literatura e videoarte, abordando-se também aspectos da intermidialidade, a partir de teóricos como Jakobson, Bachelard, Barthes, Cluver, entre outros.
\end{abstract}

Palavras-chave: Teoria Literária, videoarte, interdisciplinariedade, intermidialidade.

\section{INTERMEDIALITY AND AN INTERDISCIPLINARY APPROACH BETWEEN LITERATURE AND ARTS}

\begin{abstract}
The article discusses an interdisciplinary interface between Edgar Allan Poe' s poetry in "The adventures of Arthur Gordon Pym" and the video The Passing, by Bill Viola. It is discussed communicational theory and comparative studies, in order to relate an interpretative and a comparative possibility between literature and video art, covering also aspects of intermediality, from the theories of Jakobson, Bachelard, Barthes, Cluver and others.
\end{abstract}

Keywords: Literary Theory, video art, interdisciplinarity, intermediality.

\section{Introdução}

A partir das teorias literárias modernas, as relações entre a palavra e o mundo passaram a não mais se restringir à arte verbal, mas a todo o tipo de discurso. Esse entendimento encontrou ressonância nos estudos da teoria comunicacional, os quais tiveram o mérito de empreender o conceito de

\footnotetext{
${ }^{1}$ Mestre em Literatura pela Universidade de Brasília pelo Departamento de Teoria Literária, Linha de pesquisa "Literatura e outras Artes". Graduada em Artes Visuais e em Administração pela mesma Universidade. Endereço Eletrônico: fernandapaixao@gmail.com
} 
diálogo num sentido ampliado, como aquele que abarca toda a linguagem e não apenas a produção literária. Nesse sentido, os sujeitos e o ambiente começaram a ser compreendidos em um espaço-tempo ampliado e entendidos num processo dialógico do ato comunicativo.

Em meados do século XX, Roman Jakobson apresentou contribuições valiosas para o debate interdisciplinar entre literatura e comunicação. A abordagem do teórico russo a respeito do caráter simbólico da estrutura fônica do sistema linguístico, dos estudos sobre o som e seu significado jogou luzes nas teorias até então vigentes, ao trazer a língua para o centro dos processos comunicacionais. Segundo seu entendimento, qualquer discurso individual supõe uma troca, ou seja, não há emissor sem receptor. Com inspiração em C. S. Pierce, suscitou questões seminais no processo comunicacional ao problematizar o fenômeno da comutação de códigos pelo destinatário da mensagem. Em rasa síntese, a seu ver, a tradução intersemiótica ou transmutação consiste na interpretação dos signos verbais por meio de sistemas de signos não verbais (JAKOBSON, 1969, p. 64-5). O recorte que interessa para essa discussão do contexto da transmutação é o posicionamento de Jakobson no sentido que:

\begin{abstract}
Os procedimentos estudados pela Poética não se confinam à arte verbal. Podemos reportar-nos à possibilidade de converter O Morro dos Ventos Uivantes em filme, as lendas medievais em afrescos e miniaturas, ou L' après-midi d' un faune em música balé ou arte gráfica. Por mais irrisória que possa parecer a ideia da Ilíada e da Odisséia transformadas em história em quadrinhos, certos traços estruturais de seu enredo são preservados, malgrado o desaparecimento de sua configuração verbal. (...) Ao haver-nos com a metáfora surrealista, dificilmente poderíamos deixar de parte os quadros de Max Ernst ou os filmes de Luís Bunuel, O Cão Andaluz e A Idade do Ouro". (JAKOBSON, 1969, p.119)
\end{abstract}

Tais preceitos levaram ao entendimento de que as diferentes expressões poéticas pertencem à teoria dos signos, válida não apenas para a arte verbal, mas para todas as variedades da linguagem. Desconstruindo a ideia, em contraponto à Linguística, de que a Poética se ocuparia dos juízos de 
valor, Jakobson criticou a confusão terminológica no enquadramento do campo de estudo da Poética, ao defender o ponto de vista de que esta deve ser abarcada dentro do campo da Linguística, com o argumento de que a linguagem deve ser estudada em toda a variedade de suas funções. Sua erudição, no sentido de compreender as características inerentes a toda obra poética, culminou em fortes críticas ao modelo da teoria linguística então vigente, numa luta para invocar para o campo da linguística o direito e o dever de empreender a investigação da arte verbal em toda a sua amplitude e seus aspectos, ao defender que "todos nós que aqui estamos, todavia, compreendemos definitivamente que um linguista surdo à função poética da linguagem e um especialista de literatura indiferente aos problemas linguísticos, são, um e outro, um flagrante anacronismo" (JAKOBSON, 1963, p.162).

Esse breve recorte da teoria comunicacional teve o intuito de introduzir o debate contemporâneo sobre intermidialidade e apresentar sua conexão com as relações interartes.

\section{Os estudos comparados e o percurso dos conceitos sobre intermidialidade}

Os estudos semióticos, além de outros que giram em torno da teoria da comunicação, agregaram uma nova dimensão ao conceito de "texto" e ao seu tratamento crítico. Considerando-se que o ato de recepção é um ato de constituição textual e, ainda, que dois observadores nunca veem exatamente a mesma imagem, a situação torna-se mais complexa para o receptor. Nesse entendimento, o leitor nunca vai interpretar o mesmo texto, pois o que é dado à compreensão e à crítica como texto acaba por ser moldado pelas convenções de recepção, pelas atitudes ideológicas e ainda pelas interferências intertextuais.

Como consequência, foi oportuna a adoção de conceitos da teoria semiótica nos estudos comparados, que por sua vez teve o mérito de ampliar o leque de pesquisas dos Estudos Interartes nas últimas décadas. Conjuntamente à análise de textos literários, as obras visuais, peças musicais e mais recentemente as expressões multimídias passaram a ser analisadas 
como signos, visto que a Semiótica se revelou como importante disciplina auxiliar para a análise interdisciplinar entre texto e imagem.

A partir da abertura dialógica do texto, que permite diferentes interpretações, o semiólogo Roland Barthes problematiza: um texto, que é linguagem, pode estar fora da linguagem? Ao buscar esclarecimentos sobre o enigma, assim sugestiona:

Trata-se, por transmutação (e não mais somente por transformação), de fazer surgir um novo estado filosofal da matéria linguareira, esse estado inaudito, esse metal incandescente, fora da origem e fora de comunicação, é então coisa de linguagem e não uma linguagem, fosse esta desligada, imitada, ironizada (BARTHES, 2013, p. 39).

Em seus argumentos, Barthes reconhece a fala como um instrumento ou expressão do pensamento e a escritura como uma transliteração da fala (BARTHES, 2013, p.41). Nesse sentido, a transmutação é um conceito que tem sido adotado nas análises sobre intermidialidade, sobretudo nas práticas do cinema e da televisão. A gênese desse conceito encontra rastro na já mencionada teoria comunicacional de Jakobson: a tradução intersemiótica ou transmutação consiste na interpretação dos signos verbais por meio de signos não verbais. Na contemporaneidade, esse conceito passou a abarcar a transição entre o espaço literário e a imagem em movimento, como numa metamorfose.

É importante considerar que cada obra literária pode ter inúmeras leituras e possibilidades de tradução, justamente por sua potencialidade dialógica. As recentes teorias sobre transposição entre mídias indicam que o termo "intermidialidade" foi introduzido nos estudos comparados com esteio na teoria semiótica. Claus Cluver, reconhecido teórico norte-americano contemporâneo e professor visitante da Universidade Federal de Minas Gerais (UFMG), explica que houve uma evolução dos estudos no sentido de que:

foi decisivo para uma parte das exigências que se associam hoje aos Estudos Interartes o reconhecimento recente de que a intertextualidade sempre significa também intermidialidade - pelo menos em um dos sentidos que o conceito abrange. E isso vale não apenas 
para textos literários ou mesmo para textos verbais. Pelo menos quando se trata de obras que, seja lá em que forma, nas Artes Plásticas, na Música, na Dança, no Cinema, representam aspectos da realidade sensorialmente apreensível, sempre existe nos processos intertextuais de produção e recepção textual um componente intermidiático - tanto para a Literatura quanto, frequentemente, nas outras artes. Aos poucos isso passa a dizer respeito a fenômenos mais abstratos, como, por exemplo, a narratividade e a critérios de forma e estilo. $\mathrm{O}$ repertório que utilizamos no momento da construção ou da interpretação textual compõe-se de elementos textuais de diversas mídias, bem como, frequentemente, também de textos multimídias, mixmídias e intermídias. As comunidades interpretativas, que determinam e autorizam quais códigos e convenções nós ativamos na interpretação textual, influenciam também o repertório textual e o horizonte de expectativa. Mas o repertório é, em última análise, parte dos contextos culturais nos quais se realizam a produção e a recepção textual. (CLUVER, 2006, p. 14).

Nos estudos comparativos, partindo-se do pressuposto de que uma obra de arte é entendida como uma estrutura sígnica, os semioticistas passaram a interpretar todas as expressões artísticas como "textos", independente do sistema sígnico a que pertençam. Nessa concepção, um desenho, uma dança, um filme ou uma escultura são analisados como "textos" que se "lêem". Segundo Cluver, esta operação conduziu a uma supervalorização do modelo lingüístico, especialmente a associação do ato de "ler" e do objeto da percepção como "texto".

As análises sobre transposição intersemiótica, por se tratarem de traduções de uma linguagem para outra, podem abarcar direta ou indiretamente mais de uma mídia. São diversas as possibilidades de comunicação e representação entre os sistemas sígnicos, bem como dos códigos associados, que lançam continuamente questões sobre a base comparativa e as relações analógicas nas funções e nos efeitos dos meios analisados. No ambiente contemporâneo, Cluver argumenta que o repertório utilizado para a construção ou interpretação textual compõe-se de elementos textuais de diversas mídias. Como já enfatizado anteriormente, as artes plásticas, a dança e o cinema, por representarem aspectos da realidade 
sensorialmente apreensíveis, levaram ao entendimento sobre a possibilidade de existência de componentes intermidiáticos nos processos intertextuais. Os estudos interartes abrangem também “aspectos transmidiáticos, como possibilidades e modalidades de representação, expressividade, narratividade, questões de tempo e espaço em representação e recepção, bem como o papel da performance da música" (CLUVER, 2006, p.16).

O primeiro autor a referenciar o termo "intermídia" foi Dick Higgins, em artigo publicado originalmente em 1966. Seu texto indica que não há necessariamente um marco histórico isolado que explique o termo, mas aponta os ready mades de Marcel Duchamp como referência entre o que estaria presente no campo geral da mídia-arte. Outros artistas, como Allan Kaprow e Wolf Vostell, aos finais de 1950, começaram a adicionar ou remover de suas pinturas alguns componentes, realizando colagens e introduzindo outros objetos de uso comum em suas obras visuais. Outras inovações importantes também foram sentidas no teatro, a partir do momento em que o "teatro do absurdo" deixou de seguir o rigor do roteiro entendido como uma série de eventos sequenciais. O próprio Higgins dirigiu algumas peças e trabalhou o novo conceito atemporal do roteiro em seus happenings.

\footnotetext{
Como se o tempo e a sequência pudessem ser suspensos, não ignorando-os (o que seria simplesmente ilógico), mas sistematicamente substituindo-os como elementos estruturais ao acaso. (...) Assim o happening se desenvolveu como uma intermídia, uma terra inexplorada que fica entre a colagem, a música e o teatro" (HIGGINS, 2012, p. 45).
}

Higgins observa que a intermidialidade é muito presente, além de nas artes visuais e no teatro, na música. Nesse ponto, enfatiza a obra de John Cage, cujo trabalho explora a intermídia entre música e filosofia. Em texto posterior, publicado em 1981, Higgins reconhece ser o precursor do termo “intermídia” e que o conceito permanece no ambiente contemporâneo, no sentido de que o elemento visual se funde conceitualmente com as palavras, como na caligrafia abstrata, na poesia concreta, na poesia visual etc. O teórico conclui que a intermidialidade envolve uma fusão conceitual entre cenário, 
visualidade além do que, muitas das vezes, também são incorporados elementos de áudio.

Na década de 1970, diversos fenômenos foram conceituados como processos intertextuais, no entanto passaram, posteriormente, a serem descritos como processos intermidiáticos. De acordo com digressão feita pelo estudioso contemporâneo Jürgen Müller a respeito dos termos "intertextualidade" e "intermidialidade", as dinâmicas dos processos intermidiáticos foram praticamente negligenciadas durante esse período devido à ênfase muito pronunciada em aspectos textuais e, principalmente, literários. Em contrapartida, explica que a noção de intermidialidade teve que superar as restrições dos estudos literários e reorientar o eixo das pesquisas para interações e interferências entre diferentes mídias audiovisuais e não apenas literárias. Desta maneira, “o enfoque recaiu sobre questões de materialidade $e$ de produção de sentido, sobre características dos processos intermidiáticos $e$ funções sociais" (MÜLLER, 2012, p.85).

Essa discussão também é apreciada por Claus Cluver. Seu conceito de intermidialidade engloba a relação e a interação entre mídias. Porém, para a compreensão desse processo é preciso inicialmente definir o que se compreende do termo "mídia", pois o significado da palavra varia de uma língua para outra. No Brasil, o termo é normalmente restrito às mídias públicas e às mídias digitais. Já na língua inglesa, o leque de significado é mais amplo, pois abarca para além do conceito dos meios de comunicação, os instrumentos ou aparelhos utilizados na produção de um signo em qualquer mídia, como o corpo humano, tintas, pincel etc. Nesse ponto, Clüver enfatiza que os estudos sobre intermidialidade devem compreender apenas a linguagem dos seres humanos, pois na perspectiva do receptor é determinante o conceito de percepção sensorial da materialidade e qualidade do texto como aquela que constitui a base que determina a mídia. Assim, a percepção de uma imagem como pintura e não como serigrafia determina este processo sensível de entendimento pelo receptor do material que foi utilizado, com o ato de distinguir o uso da tinta a óleo, por exemplo. Já a questão da escrita pode ser analisada de forma particular, uma vez que possui grande expressividade, como a escrita à mão, em que a caligrafia exerce um papel determinante para 
a recepção do texto, ou na poesia concreta, que estabelece ritmo na representação figurativa do poema (CLÜVER, 2011).

Sobre a relação entre as diferentes mídias e os limites a serem impostos em razão das fronteiras existentes elas, há uma conceituação de Irina Rajewsky que propõe subcategorias para teorização das práticas midiáticas, a partir da análise de três grupos de fenômenos distintos: (1) intermidialidade no sentido estrito de transposição midiática, como as adaptações fílmicas de textos literários, novelizações etc; (2) intermidialidade no sentido estrito de combinação de mídias, o que inclui óperas, filmes, teatro, Sound Art, instalações computadorizadas, histórias em quadrinhos ou as chamadas multimídias, mescla de mídias ou intermidiáticas; e (3) intermidialidade no sentido estrito de referências intermidiáticas, como referências em um texto literário a um certo filme, gênero ou cinema em geral, ou a referência de uma pintura à fotografia etc (RAJEWSKY, 2012, p.58). Rajewsky nota que há diferenças entre a primeira categoria, que diz respeito à transposição intermidiática extracomposicional e às outras duas categorias, que correspondem a uma intermidialidade intracomposicional. A diferença entre os fenômenos reside na consequência que é gerada pela alteração no significado semiótico na intermidialidade intracomposicional. A depender da forma como se estabelecem as relações intermidiáticas, estas podem se mostrar entre duas ou mais formas midiáticas, como na Sound Art, que trabalha articulações entre o espaço arquitetônico, o objeto e o som. Não apenas Rajewsky, mas muitos autores deste campo de estudo têm convergido sobre a necessidade de definição das bordas e fronteiras entre os diferentes campos do conhecimento nos estudos intermidiáticos. A par dessa preocupação metodológica, a inserção do campo da intermidialidade nos Estudos Interartes ampliou o leque de disciplinas aos estudos comparados e as possibilidades estéticas e analíticas entre os métodos de pesquisas das diferentes áreas, diante do inelutável avanço das novas tecnologias.

\section{Literatura e videoarte: um diálogo interdisciplinar possível}

A partir da pesquisa sobre estudos comparados, observamos que a produção acadêmica sobre o diálogo interartes ampliou-se sobremaneira nas 
últimas décadas, em especial a partir de 1960. As abordagens teóricas têm se ocupado em englobar novas interpretações para além do simples comparativismo, abarcando a inclusão de estudos também entre diferentes manifestações artísticas contemporâneas, que emergiram com o surgimento de novas mídias, como a videoarte, a arte computacional etc. Assim, tornaram-se mais abundantes as convergências passíveis de serem observadas entre diferentes signos no contexto da intermidialidade. Nesse sentido, pretendemos realizar uma aproximação entre literatura e artes visuais, utilizando uma abordagem dialógica entre diferentes poéticas dentro de um contexto intermídia.

O diálogo interdisciplinar entre artes plásticas, música, literatura, dança e teatro, conjuntamente ao intenso intercâmbio de ideias do ambiente da década de 1960, cedeu espaço para que novas tecnologias fossem testadas e experimentadas em diferentes manifestações artísticas. No terreno das artes visuais desse período surgiu a videoarte, uma manifestação artística decorrente da introdução de novas mídias. O artista coreano Nam June Paik foi um de seus precursores, ao utilizar intervenções eletrônicas que modificavam as imagens transmitidas pela televisão, juntamente com o alemão Wolf Vostell, que introduziu os primeiros experimentos decollages, tendo por mote a crítica ao domínio televisivo crescente. A partir de meados dos anos 1970, a videoarte passou a ser debatida no contexto de diferentes disciplinas, como teoria dos media ou história da arte. Após diversos experimentos tecnológicos e de passeios pelo campo do documentário, os videoartistas começaram a adotar uma perspectiva diferente e ao mesmo tempo mais espiritualista, ao incorporar imagens com significados simbólicos e metafóricos aos seus trabalhos. Essas inovações estéticas encontraram referência nos clássicos do cinema (como por exemplo nos filmes de Meliés e Eisenstein), também no cinema expressionista alemão (Gabinete do Dr. Caligari de Robert Wiene), além dos filmes de cunho surrealista ( $O$ cão andaluz de Bunuel e Entreact, de René Clair (MARTIN, 2006, p.20).

A partir da década de 1980, as estruturas narrativas passaram a ser incorporadas aos trabalhos de vídeo. Os princípios norteadores de uma nova linguagem videográfica beberam na fonte dos longas metragens e, também, resgataram alguns pontos altos da literatura como, por exemplo, Finnegan' $s$ 
wake, de James Joyce. Desde esse período os teóricos têm convergido para o conceito de que o vídeo é um meio de comunicação intermédio híbrido. No cenário brasileiro, Arlindo Machado defende que o vídeo trata de "enfrentar um objeto híbrido, fundamentalmente impuro, de identidades múltiplas, que tende a se dissolver camaleonicamente em outros objetos ou a incorporar seus modos de constituição" (MACHADO, 1996, p. 46). No campo da produção videográfica no Brasil, a antropofagia de Oswald de Andrade e principalmente o filme Limite, de Mário Peixoto - pelo seu caráter poético, fragmentário e descontínuo - abriram caminho para um novo discurso nos meios audiovisuais.

Pela abertura dialógica e pela liberdade de propor narrativas nãolineares, o vídeo convida à reflexão de que se trata de uma manifestação artística baseada no tempo. A transmissão direta da mensagem audiovisual, oriunda do processo eletrônico de captação da imagem por meio de pixels, armazena o material gravado num estado de permanente possibilidade de manipulação. Além disso, recursos como o loop permitem que a fruição da imagem possa ocorrer exaustivamente à repetição, à escolha do observador. Ainda na videoarte é possível criar manipulações tecnológicas ou imagéticas que desprendam ou modifiquem a sensação da passagem do tempo.

O videoartista norte americano Bill Viola utiliza recursos metafóricos e brinca com o vasto campo entre o tempo real e o tempo do filme, afinal, como ele mesmo afirma: o vídeo "não tem começo, não tem fim, não tem duração - o vídeo é como a mente" (MARTIN, 2006, p.6). O vídeo The Passing, de 1991, mostra experiências marcantes da vida de Viola diluídas em fragmentos de imagens, com alusão intencional ao mecanismo dos sonhos. Tais imagens oníricas são intercaladas por imagens em que Viola desperta do sono, as quais se tornam perceptíveis pelo enquadramento que coloca seu olho em primeiro plano. 


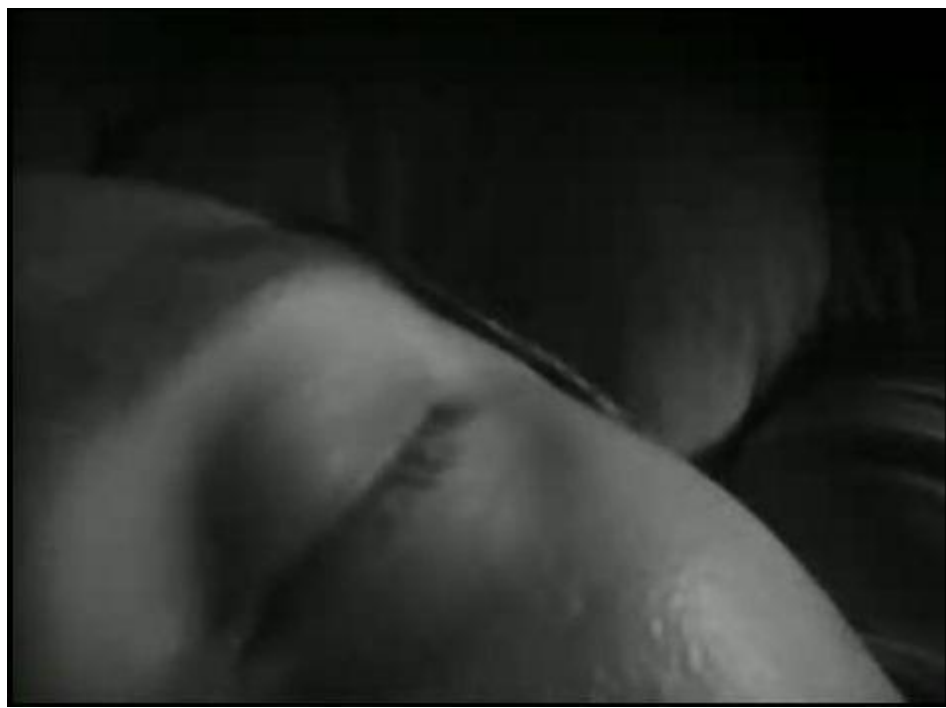

Figura 1. Stilldo vídeo The Passing, de Bill Viola, 1991.

As referências de tempo e espaço são subjetivas, uma vez que as imagens de objetos e acontecimentos se sucedem sem aparente lógica, mas se configuram como acontecimento em que, segundo Deleuze, "não é o que acontece (acidente), ele é no que acontece o puro expresso que nos dá sinal e nos espera" (DELEUZE, 2009, p. 152). Nesse sentido, fazemos referência ao modelo onírico adotado pelos surrealistas, movimento que foi diretamente afetado pela teoria freudiana sobre a estrutura psíquica ainda nos primórdios do século XX.

The Passing é considerado autobiográfico, pois envolve cenas familiares e paisagens que relembram memórias da infância, da morte da mãe e do nascimento do primeiro filho. Parece-nos que Viola, ao transmutar instantes captados de sua própria vida consegue ressignificá-los ao abordar traumas, dores e sensações no ritmo de suas impressões e memórias. Ao mostrar aquilo que está exposto em sua vida, a intenção de Viola parece ser a de revelar o seu interior, em que experiências vividas marcantes se acumulam e se transformam em leitmotivpara seus experimentos. Em sua entrevista ao Journal of Contemporary $\mathrm{Art}^{2}$, ele reafirma sua curiosidade sobre a vida e

\footnotetext{
2 Journal of Contemporary Art. Disponível em: <http://www.jca-online.com/viola.html>. Acesso em: 25 de junho de 2015.
} 
sobre o que pode acontecer após a morte. Ao mesmo tempo ele relata, nesse depoimento, a experiência de quase afogamento quando tinha dez anos, que o atingiu profundamente:

$\mathrm{Eu}$ acho que principalmente foi a curiosidade sobre a vida. A curiosidade sobre o que aconteceria quando meus parentes morreram. Para onde eles foram? Poderiam ainda serem alcançados? Curiosidades sobre um novo membro da família que nasceu. De onde veio? O que foram eles antes de estarem aqui com a gente? A curiosidade sobre as experiências pessoais parece indicar uma existência de outra ordem ou outro domínio da experiência. Lembro-me de cair em um lago quando eu tinha dez anos. Eu quase morri. A coisa que me lembro é o imaginário deste incrivelmente bonito, sereno mundo azul-verde que eu não tinha idéia que existia abaixo da superfície (tradução nossa)3.

Analisando o conjunto da obra de Bill Viola é possível dizer que o motivo que o interessa é a paisagem e a passagem dos acontecimentos, no estabelecimento de conexões entre os mundos interior e exterior. Ele parece ainda preocupado em provocar interações entre as imagens, a memória e os sonhos. Para Viola, a imagem seria apenas uma representação esquemática de um sistema muito maior, visto que o processo de ver é um processo complexo e envolve muito mais do que o reconhecimento da superfície. Seu objetivo é alcançar e tocar a voz da natureza que existe abaixo da superfície da consciência das pessoas. Ou seja, o videoartista está constantemente à procura de uma compreensão mais ampla do patrimônio espiritual da humanidade, olhando além das limitações individuais para uma mente universal mais coletiva ${ }^{4}$.

Uma das possiblidades de interpretação é pensar que o videoartista utiliza efeitos imagéticos a fim de estimular reflexões do espectador para trazer à baila a base do iceberg do que seria o inconsciente. Após diversas experimentações em laboratório, Viola criou efeitos visuais inéditos, com a

${ }^{3}$ Experimental TV Center. Disponível em: <http://www.experimentaltvcenter.org/bill-viola-installationsand-videotapes-poetics-light-and-time>. Acesso em: 25 de junho de 2015. 
finalidade de expressar as cenas oníricas da forma mais distante possível da mente consciente. Em The Passing, as cenas do artista submerso na água representam essa intenção. O uso da tecnologia eletrônica permite criar a ilusão de uma nova realidade perceptível. Na produção desse vídeo foram utilizados efeitos intensificadores, como aqueles que permitem captar imagens com o mínimo de luz, além do uso de câmeras subaquáticas. Além disso, foram utilizados jogos de luz e sombra, à maneira dos pintores barrocos, a fim de conceder um tom dramático e antitético às cenas. O resultado do uso dessas técnicas tem a potência de suscitar interpretações diferentes em cada espectador. Além disso, Bill Viola trabalhou as imagens em preto e branco, a fim de demonstrar sobriedade às imagens capturadas. Esse recurso normalmente permite intercalar imagens escondidas ou enevoadas, que aos poucos vão sendo desveladas, porém em The Passing o recurso se deu de modo inverso. As cenas em que aparece uma pequena mesa cuidadosamente arrumada - que nos lembra as naturezas mortas do pintor Chardin remetem-nos metaforicamente à mãe à beira da morte. As cenas do hospital, onde a mãe respira com dificuldade, são intercaladas por cenas dessa mesa estática. Em dado momento, imagens de forças advindas de um mundo nãonatural, fabricadas por meio de efeitos técnicos visuais, atuam lentamente sobre a mesa. A imagem começa a se pulverizar até se tornar completamente abstrata. A cena subsequente à explosão mostra o velório da mãe, o que nos leva a compreender metaforicamente o impacto da morte sendo processado no interior do artista, causado pela própria desintegração da vida materna. $\mathrm{Na}$ sequência, aparece a cena de Viola submerso na água, que remete ao seu quase afogamento quando criança, mas, ao mesmo tempo, também remete à movimentação fetal. Com uso da técnica, o videoartista consegue simbolizar imageticamente a vida e a morte.

Bill Viola apropria-se de recursos metafóricos para expressar a metafísica da existência ou a interrogação que aflige o artista em temas misteriosos como vida e morte, consciente e inconsciente, real e imaginário. As imagens da respiração da mãe no hospital e depois de seu velório; dos pés de seu filho correndo na água; os takes de seus olhos ao despertar; a derrocada da mesa arrumada; o seu mergulho nas águas profundas e as cenas da natureza bem caracterizam essa intenção. Esse conjunto de imagens teve 
inspiração nas experiências ao longo da infância e no material de que o inconsciente é alimentado 5 .

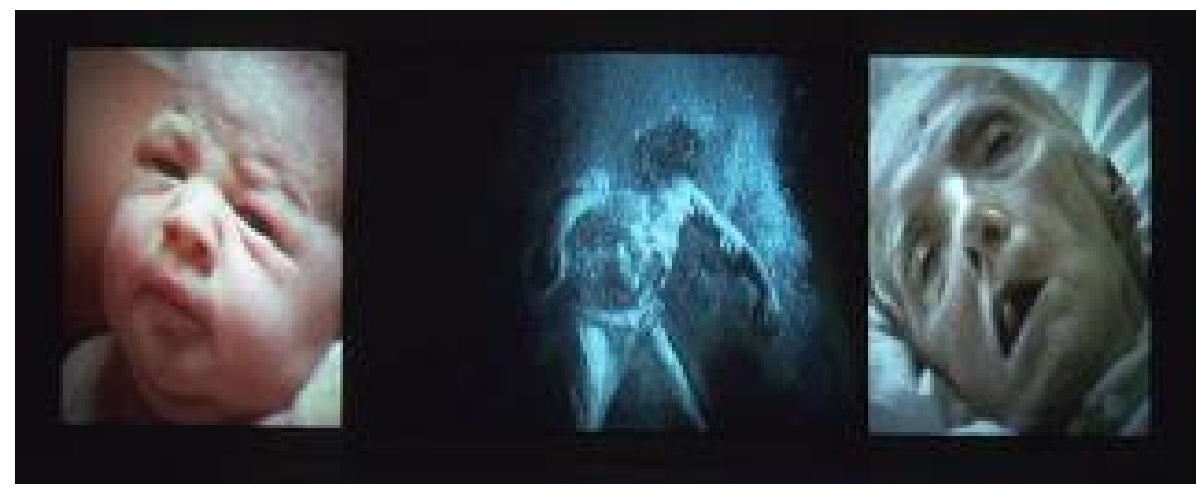

Figura 2. Montagem de imagens do vídeo The Passing, de Bill Viola, 1991.

Do ponto de vista psicanalítico, é recorrente a reflexão sobre o caráter feminino e maternal da água. Gaston Bachelard discorre sobre o tema, ao argumentar que a água é matéria que vemos nascer e crescer em toda parte; a fonte é um nascimento contínuo, que suscita devaneios sem fim ou imagens que marcam o inconsciente de quem as ama (BACHELARD, 2002, p. 15). A ideia de pureza é acrescida nesse ensaio poético, pela própria materialidade das águas límpidas e cristalinas.

Ao fazer o contraponto da imagem da água pura, Bachelard descreve as águas profundas ou a água pesada no devaneio de Edgar Allan Poe. A água seria um superlativo, uma espécie de substância mãe, porém o destino da água na poética de Poe "aprofunda a matéria, que aumenta sua substância carregando-a de dor humana" (BACHELARD, 2002, p. 56). Segundo Bonaparte, estudiosa de Poe citada por Bachelard ${ }^{6}$, a imagem que domina a poética de sua obra é a imagem da mãe moribunda. Como a morte materna assola a vida do órfão Poe, toda água primitivamente clara seria para ele uma água que deve turvar e escurecer. A poesia poemiana expressaria elementos desta química

5 Esse trecho do vídeo "The Passing" está disponível em https://www.youtube.com/watch?v=vz312dtUP5s

${ }^{6}$ As análises da poética de Edgar Allan Poe elaboradas por Marie Bonaparte são recorrentemente mencionadas por Gaston Bachelard, sobretudo no capítulo 2 de "A água e os sonhos" (p. 47-72). 
poética, ao fixar as imagens para dar a cada uma delas seu peso de devaneio interno.

A água pesada da metapoética de Edgar Poe dá exemplo de sua densidade no romance "Aventuras de Arthur Gordon Pym”. Essa obra é uma narrativa de viagens, mas também de naufrágios, que trata de uma aventura do inconsciente. Em um trecho da narrativa em que Pym esbarra numa ilha exótica após dificuldades ao mar, o aventureiro observa que a água não era límpida à primeira vista, porém, ao longo da narrativa, concluiu que a água não era incolor, nem possuía uma cor uniforme, mas oferecia todas as variedades de púrpura, feita de veias distintas, cada qual com uma cor específica (POE, 1997, p. 174-175). Esta profusão de cores na água representaria o sangue. Segundo a análise defendida em a “Água e os Sonhos”, o ser humano constantemente vai buscar na profusão do inconsciente os temas universais em experiências de sua pré-história. A morte da mãe e posteriormente da jovem esposa teriam exercido em Poe um impacto profundo em seu inconsciente, já que as páginas de seus livros trazem referências a líquidos que levam ao uso da imaginação material pelo leitor.

Para provar que a água imaginativa impõe seu devir psicológico ao universo da poética de Poe, Bachelard argumenta que a água é o verdadeiro suporte material da morte. Segundo ele, as psicologias do inconsciente ensinam que os mortos, enquanto ainda estão entre nós, são para nosso inconsciente pessoas adormecidas. O lago das águas dormentes seria o símbolo desse sono total, desse sono do qual não se deseja despertar, embalados pela lembrança, segundo os versos em Iréne, de Poe:

\author{
Semelhante a Lete, vede! O lago \\ Parece gozar de um sono inconsciente, \\ E não desejaria, por nada nesse mundo despertar; \\ O alecrim dorme sobre o túmulo \\ O lírio se estende sobre a onda \\ Toda beleza está dormindo. (BACHELARD, 2002, p. 68)
}

A água seria um convite à morte, como nos dizeres de Heráclito: “É morte, para as almas, o tornar-se água” (BACHELARD, 2002, p. 59). A água, ainda, seria o elemento que arrastaria a paisagem para o seu próprio destino. 
Mas para Bachelard até os vales mais claros tornam-se sombrios na poesia de Poe, ao citar trecho de The valley of unrest:

Outrora sorria um vale silencioso

Onde ninguém morava

Agora cada visitante confessará

A agitação do triste vale (BACHELARD, 2002, p. 65)

Roland Barthes, ao analisar o conto "O caso de M. Valdemar", propõe outra interpretação sobre a representação da água na poética de Poe (BARTHES, 1985). Este pequeno conto relata a história do senhor Valdemar, um paciente terminal que sofreu hipnose e ficou no limiar entre a vida e a morte. De acordo com Barthes, o próprio nome do conto já estaria imbuído em um conjunto de significados simbólicos. O nome Valdemar significaria a expressão de língua francesa vallée de la mer ou abismo oceânico. A escolha do nome representaria dois códigos distintos, um relacionado ao sentido sociológico e outro pertencente ao campo do simbólico. O código social estaria implícito na palavra "monsieur", que empresta a condição de realidade social, de real histórico, ou seja, o herói como integrante do meio social, portanto presente entre nós, o que traz materialidade e dá vida ao personagem. Do ponto de vista simbólico, Barthes argumenta que a profundeza dos mares certamente é um tema caro a Poe (BARTHES, 1985, p. 336). Ao realizar a análise textual do conto, o teórico afirma que a fala do paciente "- eu estou morto" ao mesmo tempo significa dois contrários: vida e morte. Assim, sob a ótica psicanalítica, a assertiva "eu estou morto" quer dizer paradoxalmente “eu não estou morto", ou seja, seria a própria invenção de uma categoria desconhecida: a verdade falsa, o sim-não, a morte-vida pensada como um inteiro indivisível, não dialético, visto que a antítese não implica nenhum terceiro termo, mas um termo único e novo. Para a psicanálise, a frase "eu estou morto" representaria um tabu: como alguém poderia enunciá-la no plano real? Assim, Barthes afirma que extraordinário em Poe é a sua loucura. Ao citar o enfoque analítico de Jacques Derrida, Barthes conclui que do ponto de vista da análise da frase "-eu estou morto", trata-se não apenas de um enunciado não crível, mas, sobretudo, de um enunciado no campo do impossível (BARTHES, 1985, p. 353). 


\section{Considerações Finais}

Em um exercício comparativo no campo interdisciplinar empreendemos uma aproximação entre literatura e artes visuais, utilizando a abordagem dialógica entre diferentes meios, ao relacionar a poética literária com a videoarte dentro de um debate sobre a intermidialidade inerente da própria expressão do vídeo.

Por um lado, a abordagem literária sob a perspectiva psicanalítica da poética de Edgar Allan Poe demonstrou a água pesada que permeia sua escritura e uma possível influência da figura materna na obra "As aventuras de Gordon Pym". O antagonismo de Poe foi observado ao interpretarmos também os construtos simbólicos da vida e da morte presentes no conto "O caso de M. Valdemar". Por outra vertente, a partir da linguagem intermidiática da videoarte, foi possível analisar alguns elementos da poética de Bill Viola na obra The Passing, pontuando-se que a utilização de recursos imagéticos e a abordagem metafórica sobre conceitos antitéticos também foram observados na produção poemiana: morte e vida, consciente e inconsciente, água turva e água limpa e, como pano de fundo, relação afetiva materna.

A análise interpretativa entre o texto poético e a videoarte representa uma das possibilidades de intersecção que aproximam universos distantes. Nesse sentido, considera-se que essa abertura de canais própria do diálogo interdisciplinar é fruto do vasto ambiente da contemporaneidade. Essa fenda permite a movimentação em diferentes direções do conhecimento o que, sem dúvida, amplia as possibilidades de análises comparativistas. A fruição das imagens em movimento e as possibilidades dialógicas com o texto poético representou esta abertura de espaço, muitas vezes construída entre opostos, que nos permitiu dar um mergulho de superfície no lago das águas e dos devaneios de Viola e Poe.

\section{Referências}

BALOCHI, Anna Maria. Conjunções, Disjunções, Transmutações. São Paulo: Annablume, ECA-USP, 1996. 
BARTHES, Roland. L'aventure Sémiologique. Paris: Édition du Seuil, 1985.

BARTHES, Roland. O rumor da língua. São Paulo: Martins Fontes, 2004.

BARTHES, Roland. A preparação do romance. Vol.II. São Paulo: Martins Fontes, 2005.

BARTHES, Roland. O prazer do texto. São Paulo: Perspectiva, 2013

CENTRO CULTURAL BANCO DO BRASIL. Bill Viola. Território do Invisível. Rio de Janeiro, 1994.

CLÜVER, Claus. Inter textus/ Inter artes/ Inter media. Revista Aletria. Belo Horizonte. Programa de Pós-Graduação em Letras - Estudos Literários. v. 6, 2006. p. 1-32.

CLÜVER, Claus. Da transposição intersemiótica in: ARBEX, Márcia (Org.). Poéticas do visível. Ensaios sobre a escrita e a imagem. Belo Horizonte: FALE, Universidade Federal de Minas Gerais, 2006.

CLÜVER, Claus. Intermidialidade. Revista do Programa de Pós-graduação em Artes da EBA/UFMG, v. 1, n. 2, 2007.

DELEUZE, Gilles. Francis Bacon e a lógica da sensação. Rio de Janeiro: Zahar, 2007.

DELEUZE, Gilles. Lógica do Sentido. Trad. Luiz Roberto Salinas. São Paulo: Perspectiva, 2009.

ECO, Umberto. Obra Aberta. São Paulo: Perspectiva, 2013.

HIGGINS, Dick. Intermídia. In: DINIZ, Thaís Flores Nogueira; VIEIRA, André Soares (Org.). Intermidialidade e estudos interartes: desafios da arte contemporânea. Belo Horizonte: Rona Editora, FALE/UFMG, 2012.

JAKOBSON, Roman. Linguística e Comunicação. São Paulo: Cultrix, 1973.

JAKOBSON, Roman. Linguística, poética e cinema. São Paulo: Perspectiva, 2007. Debates; 22, dirigida por J. Guinsburg.

MACHADO, Arlindo. Máquina e Imaginário. São Paulo: Edusp, 1996.

MACHADO, Arlindo. O vídeo e sua linguagem. Revista USP, n. 16, 1993.

MARTIN, Sylvia. Video Art. Trad. Maria do Rosário Boléo. Alemanha: Taschen, 2006. 
MÜLLER, Jurgen E. Intermidialidade revisitada: algumas reflexões sobre os princípios básicos desse conceito. In DINIZ, Thaís Flores Nogueira; VIEIRA, André Soares (Org.). Intermidialidade e estudos interartes: desafios da arte contemporânea. Belo Horizonte: Rona Editora, FALE/UFMG, 2012.

POE, Edgar Allan. O Relato de Arthur Gordon Pym. Trad. Arthur Nestrovski. Porto Alegre: L\&PM, 1997.

RAJEWSKY, Irina. A fronteira em discussão: o status problemático das fronteiras midiáticas nos debates contemporâneos sobre intermidialidade. In: DINIZ, Thaís Flores Nogueira; VIEIRA, André Soares (Org.). Intermidialidade e estudos interartes: desafios da arte contemporânea. Belo Horizonte: Rona Editora, FALE/UFMG, 2012.

VIOLA, Bill. Experimental TV Center. Disponível em: <http://www. experimentaltvcenter.org/bill-viola-installations-and-videotapes-poeticslight-and-time>. Acesso em: 25 de jun. 2015.

VIOLA, Bill. Journal of Contemporary Art. Disponível em: <http://www.jcaonline.com/viola.html>. Acesso em: 25 de jun. 2015.

The facts in the case of M. Valdemar. Disponível em: <http://www.eapoe.org /works/tales/vldmard.htm > Acesso em: 24 de jan. 2016.

Recebido em 30 de abril de 2017.

Aceito em 26 de maio de 2017. 